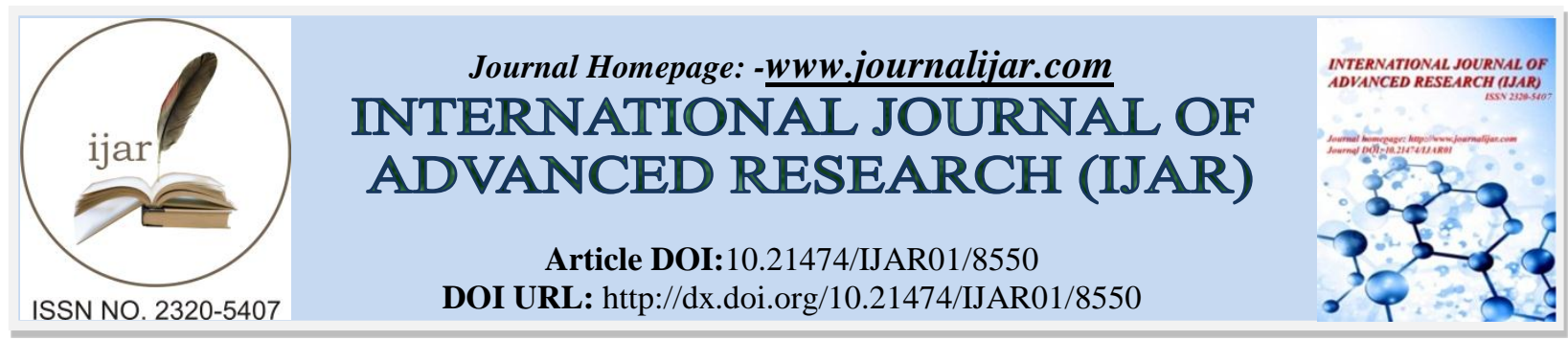

RESEARCH ARTICLE

\title{
INVESTIGATING THE PRODUCT QUALITY AND E-SERVICE QUALITY ATTRIBUTES THAT INFLUENCE CUSTOMERS SATISFACTION OF ONLINE APPARELS.
}

Yuhanis Mohamed Noor, Noorshella Che Nawi, Noorul Azwin Md Nasir and Nurhaiza Nordin. Faculty of Entrepreneurship and Business, Universiti Malaysia Kelantan City Campus, 16100 Kota Bharu.

\section{Manuscript Info}

\section{Manuscript History}

Received: 14 December 2018

Final Accepted: 16 January 2019

Published: February 2019

Key words:-

Product Quality, E-services Quality, Customers Satisfaction, Online Apparels.

\begin{abstract}
This study has to investigating the product quality and the e-service quality attributes that influence customer's satisfaction of online apparels. Hussain and Ranabhat (2013) appended product quality as extension for a product that can be succeeds to meet customers' needs. Therefore, this can described that product quality can be one of the vital tools to maintain the competitive advantage in market which is designed to undergo the product development process to achieve the consumer satisfaction and upgrade the quality of performance (Gharakhani, Rahmati, Farrokhi, \& Farahmandian, 2013; C.-H. Wang, Chen, \& Chen, 2012)Sousa and Voss (2012) and Sura and Ahn (2017), service quality can defined as the total servicers that provided by the service providers. This study adapted a model from Garvin (1984) in measuring product quality which consist of eight variables namely performance, features, reliability, conformance, durability, serviceability, aesthetics and perceived quality and the dimensions of eservice quality in this study are assurance, empathy, responsiveness, reliability, and perceived usefulness. By using SPSS and PLS for analysis the data with 389 respondents were involved in this research by participating in online survey. The result was found that product quality has a positive relationship with the customer satisfaction in purchasing apparel online and perceived quality is found to be the most affected factors on product quality. In addition, results also shows that e-service quality is significant determinant of customer satisfaction in purchasing apparel online Specifically, perceived usefulness is found to be the most dominant contributor to customer satisfaction of online apparels.
\end{abstract}

Copy Right, IJAR, 2019,. All rights reserved.

\section{Introduction:-}

As online business or electronic business became important and continues to rise, there are also increase in the number of consumer purchase through the net. Among all products purchased online, apparel purchases represent one of the increasing trends in online shopping (San Lim, Heng, $\mathrm{Ng}$, \& Cheah, 2016). Critics said online apparel purchasing was difficult in the early days of e-commerce because of consumers who like to touch and physically try on clothes. However, this changed recently when the volume of apparel sold, including shirts, footwear and fashion adornments increased steadily and online revenues for fashion or apparel websites have grown also (Y.Lim, P.Heng,

Corresponding Author:-Yuhanis Mohamed Noor.

Address:-Faculty of Entrepreneurship and Business, Universiti Malaysia Kelantan City Campus, 16100 Kota Bharu. 
When online apparel purchase became common, consumers became more accepting of it. San Lim et al. (2016) claimed that many shoppers show strong enthusiasm and confidence in purchasing apparel using the Internet. In the USA, online apparel provides the highest revenue amongst online product categories (San Lim et al., 2016). eMarketer (2012) reported that online apparel merchandise in the USA reached $\$ 34.2$ billion in 2012. The same phenomenon happened in Asia, for example in Taiwan, online apparel has become the biggest category of merchandise in online sales (Y. Wang \& Cho, 2012). Annual sales in Taiwan have shown the increasing rate of over $30 \%$ of total online sales every year.

Online shopping has become a popular trend nowadays. By having a good Internet connection and smart devices, people can simply click and do online shopping at anytime and anywhere. Online shopping which is the glorious invention that allows people to buy things from the comfort of their homes. No more travelling to multiple stores to find the right product; no more having to deal with over-enthusiastic sales persons; no more standing in long lines at the checkout counter. The e-commerce boom has certainly changed the way people shop for the better. But, like everything else, the world of online shopping is not all good. Despite all the efforts of e-commerce companies to alleviate them, there are a few problems that customers still have to face while shopping online.

The biggest problem while buying things online is that there's no guarantee of a product's quality. Reviews are not always reliable and all the research can't assure of a product's quality; fraudulent sellers who intentionally mislead customers to increase sales are the prime reason for faulty/sub-par products being sold online. With the volume of goods e-commerce companies handle these days, it can be quite difficult for them to conduct quality checks on each and every one of the products they're selling. Additionally, the issue of getting the correct size remains a serious drawback for buying clothing and footwear online. Sizes vary from brand to brand, and since customers can't try out the products before buying them, selecting the size is always a gamble. Thus, the objective of this study is to investigate the E-service quality attributes that influence customers' satisfaction of online apparels.

\section{Literature Reviews \\ Product Quality}

Based on Hussain and Ranabhat (2013) appended product quality as extension for a product that can be succeeds to meet customers' needs. Therefore, this can describe that product quality can be one of the vital tools to maintain the competitive advantage in market which is designed to undergo the product development process to achieve the consumer satisfaction and upgrade the quality of performance (Gharakhani, Rahmati, Farrokhi, \& Farahmandian, 2013; C.-H. Wang, Chen, \& Chen, 2012). Typically, there are eight dimensions proposed by D. A. Garvin (1984) and D. Garvin (1987) as the basic elements for product quality: performance, features, reliability, conformance, durability, serviceability, aesthetics, and perceived quality. D. Garvin (1987) argued that each elements of product quality are definite and self-contained. In other words, a product might be rank in high position or low position in each dimension. This can explain that a company can position their products in market place by identifying the influence or interaction between eight elements of quality since quality is a strategic variable (D. A. Garvin, 1984).

The dimensions that provided by D. A. Garvin (1984) and D. Garvin (1987) were developed variety empirical investigations in the past study. A study from Workman and Cho (2012) as support to the multidimensional nature of product quality. Furthermore, Trentin, Perin, and Forza (2012) expanded the multidimensional approach to study manufacturing quality. Moreover, a study from found that the product design management is similar important as the product quality management. Therefore, the researcher strongly recommended the Garvin's proposed dimensions as knowledgeable kit for studying a product quality.

The sellers either in traditional stores or online stores been studying about the ways for consumers evaluate the garments products since long times ago. Indeed, quality always becoming elusive question continuously towards garments items (Jaskulska, 2013). A study from Gitimu, Workman, and Robinson (2013) argued that consumers tend to use various informational cues in order to judge the garments' quality that includes products' characteristics such as materials and price (intrinsic and extrinsic cues). However, Jaskulska (2013) argued that consumer not limited to judge the garments products based on information as well as the abstract features of garments products includes beauty and durability (aesthetics and performance cues) also become a determinant factor. Therefore, this reflects that some consumers tend to principal informational cues when doing quality evaluation. Indeed, study from Jaskulska (2013) applicable quality dimensions to make evaluation for garments products in traditional stores. Therefore, this inspired the researcher to adopt the Garvin's proposed dimensions to carry out this study towards online garments products. 


\section{E-services Quality}

Based on Sousa and Voss (2012) and Sura and Ahn (2017), service quality can define as the total servicers that provided by the service providers. However, service quality in e-commerce context can be defined as the total supporting services were delivered and provided by e-commerce service provide (Sura \& Ahn, 2017). Indeed, several past studies such as Sura and Ahn (2017) and Chiu, Wang, Fang, and Huang (2014) clarified that the ecommerce services play bigger roles as supporter for consumers in e-commerce and directly influence customer satisfaction. Besides, Ha and Stoel (2012) added service quality becomes essential in order to increase customer satisfaction as supported by the review from Nadeem, Andreini, Salo, and Laukkanen (2015). According to Parasuraman, Zeithaml, and Berry (1988) service quality includes five elements which are tangible, assurance, empathy, responsiveness, and reliability.

However, the researcher tends to remove the tangible elements in this study. This is due to Chodzaza and Gombachika (2013) defined that tangible elements are suitable to identify perspective among consumers when dealing with hardware and software systems. Therefore, tangible elements can be removed since this study is focus on the services that provided from social media seller. Meanwhile, Nadeem et al. (2015) argued that two elements which are reliability and responsiveness are important to determine the service quality especially in online context. In result, reliability and responsiveness been adopted by the research to identify the service quality in this study.

Nadeem et al. (2015) added empathy are the least importance elements in e-commerce due to the online environment least occur personal human interaction. However, Sura and Ahn (2017) argued that social media capable to provide real communication and interaction between customers which results empathy can be possible and relevant. Based on the review from Sura and Ahn (2017), the researcher adopt empathy in this study as measurement for service quality. Several past studies such as Behjati, Nahich, and Othaman (2012) replaced assurance into trust or security and privacy in the study. Lin and Wang (2015) argued that assurance can be occur by the security and privacy of the system. In other words, assurance includes courtesy and capability of system to create the sense of trust of confidence. This result the researcher adopt assurance in this study. According to Sura and Ahn (2017) stated that perceived usefulness capable to result high customer satisfaction in e-commerce systems since perceived usefulness contains the meaning of attitude. In a nutshell, the dimensions of e-service quality in this study are assurance, empathy, responsiveness, reliability, and perceived usefulness.

\section{Methodology:-}

This study employed the cross-sectional design and a quantitative approach to measure the effect of customer's satisfaction in purchasing apparel through online. Google form was used as a platform to gather data due to complimenting features of Google, such as Docs editor. Later the data was imported into SPSS and PLS for analysis.

\section{Research Instrument}

The questionnaire for online survey was designed using simple and unbiased wordings so that the respondents could easily understand the questions. Table 1 below provided a summary of each variable and its sources. A seven-point Likert scale (very strongly disagree, strongly disagree, disagree, neutral, agree, strongly agree and very strongly agree) was used for all the variables.

Table 1:-List of variables and sources

\begin{tabular}{|c|c|c|}
\hline Variable & Items & Source \\
\hline Product quality & $\begin{array}{ll}\text { - } & \text { Features (4 items) } \\
\text { - } & \text { Durability (4 items) } \\
\text { - } & \text { Performance (4 items) } \\
\text { - } & \text { Aesthetic (4 items) } \\
\text { - } & \text { Perceived quality (4 items) } \\
\text { - } & \text { Reliability (4 items) } \\
\text { - } & \text { Conformance (4 items) } \\
\text { - } & \text { Serviceability (4 items) }\end{array}$ & - Jaskulska, J. (2013) \\
\hline E-service quality & $\begin{array}{ll}- & \text { Assurance (4 items) } \\
- & \text { Empathy ( } 4 \text { items) } \\
- & \text { Responsiveness ( } 4 \text { items) } \\
- & \text { Reliability (4 items) } \\
- & \text { Perceived usefulness (4 items) } \\
\end{array}$ & - $\quad$ Sura, S., \& Ahn, J. (2017). \\
\hline
\end{tabular}




\begin{tabular}{|l|l|l|}
\hline Customer Satisfaction & -4 items & $-\quad$ Jaskulska, J. (2013)
\end{tabular}

\section{Sample Selection and Data Collection}

The population includes online shopping users in Malaysia who were experienced on buying cloth from the net. According to the report of Internet Users Survey 2017 by Malaysian Communications and Multimedia Commission (MCMC), there were 24.5 million Internet users in Malaysia and about $48.8 \%$ has made purchases via online platform with total of 11,956, 000 online users. Respondents' participation is based on voluntary basis or so called self-administered. This sampling method was being used because the respondents are accessible and cooperative. Besides that, this method is also less expensive and required minimum time compared to the other techniques such as systematic sampling and area sampling.

According to Malhotra (2010), the nature of the research would have an impact on selecting the sample size. According to Sekaran and Bougie (2016), sample is a subset of the population. The number of respondents has been selected from the population for research purpose. This study is considered the common rule for the unknown population emphasized by Hair, Celsi, Money, Samouel, and Page (2016). The sample size was at least five times more than items to be analysed. (Fives \& Looney, 2009). Since the study consists of 56 items in questionnaire, hence, 255 respondents are required in this research. Thus, in order to ensure that it could obtain at least 255 samples from its population, a total number of 400 questionnaires was distributed to the respondents for this study and this study managed to get 332 respondents.

\section{Data Analysis Methods:-}

This study used the Partial Least Square (PLS) technique to analyse data by employing the SmartPLS 2.0 software for validating measurements and testing the hypotheses. The Partial Least Squares (PLS) approach was applied to estimate the causal models, following Hulland's (1999) procedure, which suggested evaluating each model in two stages. This method provides the basics of estimating, and the parsimonious model on the higher-level analysis with the presence of the Lower Order Constructs (LOCs) (Becker et al., 2012). The evaluation of the measurement model is based on the assessment of internal consistency (CR), indicator reliability (Cronbach's Alpha), convergent validity (AVE), and discriminant validity. The values of composite reliability and AVE to test the reliability and validity of the constructs revealed that the values are greater than 0.5 for all the constructs thus the construct reliability and convergent validity were achieved and explained. Succeeding, the discriminant validity for each measure was calculated. Finally, in the second stage, the paths between the constructs in the models were estimated.

\section{Data Analysis Results:-}

Table 2:-Descriptive Analysis

\begin{tabular}{|c|c|c|c|}
\hline & & Frequency & Percent \\
\hline \multirow[t]{2}{*}{ Gender } & Female & 256 & 77.1 \\
\hline & Male & 76 & 22.9 \\
\hline \multirow[t]{4}{*}{ Age } & 17 and below & 3 & .9 \\
\hline & $18-29$ & 265 & 79.8 \\
\hline & $30-39$ & 44 & 13.3 \\
\hline & 40 and above & 20 & 6.0 \\
\hline \multirow{6}{*}{$\begin{array}{l}\text { Amount } \\
\text { Spend }\end{array}$} & Rm 50 and below & 115 & 34.6 \\
\hline & RM 51- RM 100 & 94 & 28.3 \\
\hline & RM 101- RM 150 & 62 & 18.7 \\
\hline & RM 151- RM 200 & 25 & 7.5 \\
\hline & RM 201- RM 250 & 16 & 4.8 \\
\hline & RM 251 and above & 20 & 6 \\
\hline \multirow{5}{*}{$\begin{array}{l}\text { Hour } \\
\text { Spent }\end{array}$} & $<1$ hour & 33 & 9.9 \\
\hline & $1-3$ hour & 127 & 38.3 \\
\hline & 4-6 hours & 105 & 31.6 \\
\hline & 7-9 Hours & 41 & 12.3 \\
\hline & 10 Hours and above & 26 & 7.8 \\
\hline
\end{tabular}




\section{Reliability and Validity}

The Cronbach's Alpha values for After Sale Risk, Delivery Risk, Privacy Risk, Product-Performance Risk, Psychological Risk, Social Risk, Time or Convenience Risk, and Online Purchasing Behaviour were all found to be more than 0.7. As for Financial Risk, the Cronbach's Alpha was found to be 0.680. Since the Cronbach's alpha for most of the indicators were found to be more than 0.7, following Hair, Ringle, and Sarstedt (2013), this study considered all items to be reliable. For the composite reliability, the indicators of this study have different loadings for all items at more than 0.7. According to experts, if the indicators' value for composite reliability are higher than 0.7, it is considered reliable (c.f. Hair et al., 2013). Convergent validity signifies that a set of indicators represents one and the same underlying construct, which can be demonstrated through their unidimensionality, and since the average variance extracted (AVE) value for all items is found to be more than 0.5, this indicates sufficient convergent validity for all items of this study (c.f. Hair, Ringle, and Sarstedt, 2011) (see Table 3).

Table 3:-Reliability Analysis

\begin{tabular}{|c|c|c|c|c|}
\hline & Cronbach's Alpha & rho_A & CR & (AVE) \\
\hline E-SQ & 0.96 & 0.962 & 0.963 & 0.567 \\
\hline PQ & 0.934 & 0.938 & 0.941 & 0.503 \\
\hline SATISFACTION & 0.906 & 0.907 & 0.934 & 0.78 \\
\hline
\end{tabular}

Note: CA: Cronbach's Alpha; DG rho - Dillon-Goldstein's rho; CR - Composite Reliability; AVE - Average

Variance Extracted; VIF - Variance Inflation Factors

Source: Author's data analysis

Table 4:-Outer Model Loading and Cross Loading

\begin{tabular}{|l|r|r|r|}
\hline & E-SQ & PQ & SATISFACTION \\
\hline AES_3 & 0.547 & 0.754 & 0.483 \\
\hline ASSUR_1 & 0.694 & 0.577 & 0.523 \\
\hline ASSUR_2 & 0.696 & 0.518 & 0.561 \\
\hline ASSUR_3 & 0.668 & 0.486 & 0.466 \\
\hline ASSUR_4 & 0.774 & 0.567 & 0.611 \\
\hline CONF_1 & 0.53 & 0.649 & 0.477 \\
\hline CONF_2 & 0.472 & 0.685 & 0.404 \\
\hline CONF_3 & 0.491 & 0.69 & 0.467 \\
\hline CONF_4 & 0.499 & 0.721 & 0.479 \\
\hline CS_1 & 0.722 & 0.56 & 0.896 \\
\hline CS_2 & 0.72 & 0.546 & 0.896 \\
\hline CS_3 & 0.652 & 0.534 & 0.865 \\
\hline CS_4 & 0.701 & 0.583 & 0.874 \\
\hline DUR_1 & 0.482 & 0.737 & 0.443 \\
\hline DUR_2 & 0.481 & 0.715 & 0.449 \\
\hline DUR_3 & 0.462 & 0.671 & 0.37 \\
\hline EMP_1 & 0.738 & 0.5 & 0.535 \\
\hline EMP_2 & 0.69 & 0.479 & 0.432 \\
\hline EMP_3 & 0.764 & 0.49 & 0.536 \\
\hline EMP_4 & 0.756 & 0.462 & 0.545 \\
\hline PQ_1 & 0.372 & 0.598 & 0.368 \\
\hline PQ_2 & 0.57 & 0.737 & 0.551 \\
\hline PQ_3 & 0.57 & 0.796 & 0.528 \\
\hline PQ_4 & 0.597 & 0.804 & 0.524 \\
\hline
\end{tabular}




\begin{tabular}{|c|c|c|c|}
\hline PU_1 & 0.802 & 0.601 & 0.731 \\
\hline PU_2 & 0.759 & 0.512 & 0.65 \\
\hline PU_3 & 0.772 & 0.508 & 0.708 \\
\hline PU_4 & 0.768 & 0.57 & 0.721 \\
\hline REAL_1 & 0.724 & 0.499 & 0.535 \\
\hline REAL_2 & 0.777 & 0.582 & 0.601 \\
\hline REAL_3 & 0.759 & 0.549 & 0.572 \\
\hline REAL_4 & 0.795 & 0.557 & 0.618 \\
\hline RESP_1 & 0.778 & 0.537 & 0.585 \\
\hline RESP_2 & 0.764 & 0.494 & 0.558 \\
\hline RESP_3 & 0.778 & 0.501 & 0.667 \\
\hline RESP_4 & 0.781 & 0.527 & 0.609 \\
\hline SER_1 & 0.475 & 0.677 & 0.388 \\
\hline SER_2 & 0.418 & 0.678 & 0.355 \\
\hline SER_3 & 0.476 & 0.724 & 0.372 \\
\hline SER_4 & 0.405 & 0.679 & 0.372 \\
\hline \multicolumn{4}{|c|}{ Fornell -Larcker Criterion } \\
\hline E-SQ & 0.753 & 0 & 0 \\
\hline PQ & 0.699 & 0.709 & 0 \\
\hline SATISFACTION & 0.792 & 0.63 & 0.883 \\
\hline \multicolumn{4}{|c|}{ Heterotrait-Monotrait Ratio } \\
\hline E-SQ & 0 & 0 & 0 \\
\hline PQ & 0.732 & 0 & 0 \\
\hline SATISFACTION & 0.838 & 0.675 & 0 \\
\hline
\end{tabular}

Moreover, indicators could be assumed to be reliable if the absolute standardized outer loadings are higher than 0.7. As presented in Table 4, all items used to measure Product Quality (features, durability, performance, aesthetic, perceived quality, reliability, serviceability and conformance), E-service Quality (perceived usefulness, reliability and responsiveness) and Customer Satisfaction are found to be more than 0.7. The cross-loading values are far below the outer loadings, which suggest good discriminant validity. Experts note that to assess the discriminant validity, the cross loadings of the indicators should be examined (Hair, Hult, Ringle,and Sarstedt, 2014). The Fornell-Larcker assesses the discriminant validity at the construct level. The Fornell-Larcker criterion in Table 4 is largely unable to detect any lack of discriminant validity. Furthermore, the Heterotrait-Monotrait Ratio (HTMT) is an estimate of the correlation between constructs, which parallels the deattenuated construct score creation. Using a value of 0.9 as the threshold, this study concluded that there is no evidence of a lack of discriminant validity and all the constructs meet the criteria.

\section{Path Coefficients}

Path coefficients are estimated as path relationships in the structural model between the constructs in the model. As presented in Table 5 below, the path coefficients between product quality and e-service quality have significant relationship with customer satisfaction (at the chosen $5 \%$ level of significance). In respect to the effect sizes $\left(\mathrm{f}^{2}\right.$ ) as observed in Table 5, e-service quality is found to have zero to substantial effect size to satisfaction in purchasing apparel online in Malaysia while product quality is found to have small effect size to satisfaction in purchasing apparel online in Malaysia.

Table 5:-Path Coefficient

\begin{tabular}{|c|c|c|c|c|c|}
\hline 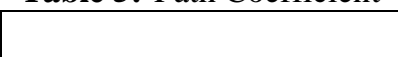 & Coefficient & t-value & p-values & $\mathbf{f}^{2}$ & Decision \\
\hline E-SQ -> SATISFACTION & 0.689 & 14.219 & 0 & 0.670 & Accept \\
\hline
\end{tabular}




\begin{tabular}{|l|l|l|l|l|l|}
\hline PQ -> SATISFACTION & 0.148 & 0.050 & 0.003 & 0.031 & Accept \\
\hline
\end{tabular}

\section{Discussion:-}

In order to extend existing literature and enable online retailer especially selling apparel to satisfy the consumer, this study examined the effect of product quality and e-service quality on customer satisfaction in purchasing apparel online. The findings from the study revealed that product quality has a positive relationship with the customer satisfaction in purchasing apparel online confirming hypothesis one $\left(\mathrm{H}_{1}\right)$. The finding appears to support the previous research done by Lemmink and Kasper (1994) appended product quality as extension for a product that can be succeeds to meet customers' needs. This is no doubt that product quality is important tools for company designed the product development process in order to achieve consumer satisfaction as well as to upgrade the performance quality in result to sustain in current market (Gharakhani et al., 2013; Wang et al., 2012). Therefore, it is believed that online apparel sold through the net are considered as quality products. Perceived quality is found to be the most affected factors on product quality. In other words, customer who purchase apparel online seek for a quality, wellknown brand and value for their money in order to satisfy their purchasing. This is aligned with the past studies by Jaskulska (2013) and Tsyewu (2013) who found that perceived quality of the product such as well known brand and price effected their satisfaction when purchasing online. As for the e-service quality, findings of this study is in line with the previous studies ( eg. Behjati, Nahich, and Othaman (2012), Chiu et al., (2014) ), indicating that e-service quality is significant determinant of customer satisfaction in purchasing apparel online $\left(\mathrm{H}_{2}\right)$. Specifically, the perceived usefulness is the most affecting factor on e-service quality. The result of this study implies that, perceived usefulness is found to be the most dominant contributor to customer satisfaction of online apparels, it is important for marketers to consider the degree of perceived usefulness in giving service through social media on their marketing programs as it is a vital influential factor that significant impact towards customer decisions to adopt the online shopping activities in social media. This also can be supported by the review from Chiu et al. (2014) appended if the degree of perceived usefulness in a system is higher, the likely for customers satisfaction.

\section{Conclusion:-}

The research aim to investigate the effect of customer's satisfaction in purchasing apparel through online. Independent variables used are product quality and e-service quality. The proxies of product quality are features, durability, performance, aesthetic, perceived quality, reliability, conformance and serviceability. Whereas, the proxies for e-service quality are the assurance, empathy, responsiveness, reliability and perceived usefulness. From the findings, it shows product quality has a positive relationship with the customer satisfaction in purchasing apparel online. Where perceived quality is found to be the most affected factors on product quality. In addition, results also shows that e-service quality is significant determinant of customer satisfaction in purchasing apparel online Specifically, perceived usefulness is found to be the most dominant contributor to customer satisfaction of online apparels.

\section{Acknowledgments:-}

This study was funded by the RMIC, Universiti Malaysia Kelantan, Malaysia; under the grant titled 'Short Term Research Grant (SGJP)'. Project title Investigating the Product Quality Attributes and E-Services Quality Attributes that Influence Customer Satisfaction of Online Shopping Products. Total grant: RM5000.00 (Ringgit Malaysia).

\section{Author Contributions:}

Lead author (Mohd Nor, Yuhanis); prepared the research proposal, managed the research project, questionnaire design, data analysis, and wrote this paper. The remaining authors contributed in developing the research model, literature review, sample selection, data collection and preparing the manuscript.

\section{Conflicts of Interest:}

The authors declare no conflict of interest.

\section{References:-}

1. Behjati, S., Nahich, M., \& Othaman, S. N. (2012). Interrelation between e-service quality and e-satisfaction and loyalty. European Journal of Business and Management, 4(9), 75-85.

2. Chen, J. V., Rungruengsamrit, D., Rajkumar, T., \& Yen, D. C. (2013). Success of electronic commerce Web sites: A comparative study in two countries. Information \& Management, 50(6), 344-355. 
3. Chodzaza, G. E., \& Gombachika, H. S. (2013). Service quality, customer satisfaction and loyalty among industrial customers of a public electricity utility in Malawi. International Journal of Energy Sector Management, 7(2), 269-282.

4. Frank, B., Torrico, B. H., Enkawa, T., \& Schvaneveldt, S. J. (2014). Affect versus cognition in the chain from perceived quality to customer loyalty: The roles of product beliefs and experience. Journal of retailing, 90(4), 567-586.

5. Garvin, D. (1987). Competing on the eight dimensions of quality. Harv. Bus. Rev., 101-109.

6. Garvin, D. A. (1984). Product quality: An important strategic weapon. Business horizons, 27(3), 40-43.

7. Gerolamo, M. C., Poltronieri, C. F., Yamada, T. T., \& Cintra, A. L. (2014). Quality Management: How do Brazilian Companies use it? Procedia-Social and Behavioral Sciences, 143, 995-1000.

8. Gharakhani, D., Rahmati, H., Farrokhi, M. R., \& Farahmandian, A. (2013). Total quality management and organizational performance. American Journal of Industrial Engineering, 1(3), 46-50.

9. Gitimu, P. N., Workman, J., \& Robinson, J. R. (2013). Garment quality evaluation: Influence of fashion leadership, fashion involvement, and gender. International Journal of Fashion Design, Technology and Education, 6(3), 173-180.

10. Ha, S., \& Stoel, L. (2012). Online apparel retailing: roles of e-shopping quality and experiential e-shopping motives. Journal of Service Management, 23(2), 197-215.

11. Hussain, M., \& Ranabhat, P. (2013). Influence of service and product quality on customer retention: A Swedish grocery store. University of Gävle, Sweden.

12. Jaskulska, J. (2013). Quality of service and product as the main factors influencing customers' satisfaction in the clothing retailing industry in Ireland-case study of Zara Plc. Dublin Business School.

13. Nadeem, W., Andreini, D., Salo, J., \& Laukkanen, T. (2015). Engaging consumers online through websites and social media: A gender study of Italian Generation Y clothing consumers. International Journal of Information Management, 35(4), 432-442.

14. Parasuraman, A., Zeithaml, V. A., \& Berry, L. L. (1988). Servqual: A multiple-item scale for measuring consumer perc. Journal of retailing, 64(1), 12-40.

15. San Lim, Y., Heng, P. C., Ng, T. H., \& Cheah, C. S. (2016). Customers' online website satisfaction in online apparel purchase: A study of Generation Y in Malaysia. Asia Pacific Management Review, 21(2), 74-78.

16. Sousa, R., \& Voss, C. (2012). The impacts of e-service quality on customer behaviour in multi-channel eservices. Total Quality Management \& Business Excellence, 23(7-8), 789-806.

17. Sura, S., \& Ahn, J. (2017). The effects of service quality determinants on social networking site-based commerce: the Malaysian customers' perspective. Total Quality Management \& Business Excellence, 1-15.

18. Trentin, A., Perin, E., \& Forza, C. (2012). Product configurator impact on product quality. International Journal of Production Economics, 135(2), 850-859.

19. Tsyewu, O. A. (2013). The influence of constructional factors on the serviceability and discard of custom-made clothing among female students in the university of cape coast. university of cape coast.

20. Wang, Y., \& Cho, H. (2012). The effect of fashion effectiveness on consumer's online appear customization. International Journal of Organizational Innovation, 5(2), 263-283. 